\title{
Urinalisis pada urin kucing dengan kasus feline urologic syndrom di klinik hewan La Femur Surabaya
}

\author{
Desty Apritya ${ }^{1, *}$, Sinawang Suryaning Kartika ${ }^{2}$ \\ ${ }^{1}$ Fakultas Kedokteran Hewan, Universitas Wijaya Kusuma, Surabaya \\ ${ }^{2}$ Klinik Hewan La Femur, Surabaya
}

\begin{abstract}
ABSTRAK: Tujuan dari penelitian ini adalah untuk menganalisis urin berdasarkan kejadian feline urologic syndrom (FUS) di klinik hewan La Femur Surabaya terhadap terbentuknya albumin, eritrosit serta kristal urin. Metode penelitian ini menggunakan purposive sampling. Sampel urin dari 15 pasien yang dianalisis merupakan urin dari kucing yang terdiagnosa FUS dengan gejala klinis berupa stranguria, anuria, pollakiuria, hematuria serta pada palpasi abdomen terdapat distensi vesika urinaria. Analisis urin dilakukan dengan metode dipstick dan mikroskopik. Hasil urinalisis ditemukan positif albumin sebesar 53,3\% dan eritrosit sebesar $80 \%$. Pemeriksaan mikroskopis menunjukkan kristal kalsium oksalat $40 \%$, struvit $13 \%$ dan tidak ditemukan kristal (negatif) $47 \%$.
\end{abstract}

Kata kunci:

feline urologic syndrom, kucing, albumin, eritrosit, kristal urin

\section{- PENDAHULUAN}

Feline Urologic Symdrome (FUS) atau dapat dikenal juga dengan Feline Lower Urinary Tractus Disease (FLUTD) adalah penyumbatan saluran kemih pada bagian bawah. Penyebabnya antara lain infeksi bakteri, neoplasia, kelainan anatomi, masalah kebiasaan/behaviour, feline idiopathic atau interstitial cystitis, kristal urolit dan gangguan persyarafan (Hostutler et al. 2005). Hasil identifikasi mineral penderita urolit antara lain struvit, kalsium oksalat, urat, bekuan darah, patit, brushit, sistin, silika, potasium magnesium piropospat, xantin, dan newberyte (Mihardi dkk. 2018). Menurut Little (2012), penyebab urolit lainnya adalah eritrosit kering yang membeku sehingga dapat menyebabkan obstruksi uretra. Kasus FLUTD pada tahun 2017 di Surabaya dilaporkan sebanyak 30 terjadi dalam kurun waktu dua bulan. Kasus FUS ditunjukkan dengan gejala stranguria, anuria, pollakiuria, hematuria dan terdapat distensi pada pemeriksaan palpasi vesika urinaria (Tariq et al. 2014). Penderita umumnya merupakan kucing jantan. Kucing yang mengalami obesitas dan kurang aktif (malas bergerak), selalu berada di area indoor, memakan makanan kering dan sedikit minum memiliki insidensi lebih besar sebagai faktor resiko (Kerr 2013).

\section{- MATERI DAN METODE}

Sampel urin kucing sebanyak 15 buah didapatkan di Klinik Hewan La Femur Surabaya yang terdiagnosa FUS (Gambar 1). Sampel urin sebanyak 1-2 ml diambil dengan menggunakan kateter kucing. Pemeriksaan laboratorium dilakukan menggunakan metode dipstick dan mikroskopik.
Pemeriksaan metode dipstick dilakukan dengan meletakkan satu strip kertas dipstick di atas handuk atau tissue kertas bersih, lalu urin diteteskan pada setiap sisi test pad. Sedangkan pada pemeriksaan mikroskopik dilakukan dengan cara: urin sebanyak 2-3 ml disentrifugasi dengan kecepatan 3000 rpm selama 5 menit, kemudian endapan diambil untuk dilakukan pengamatan. Beberapa tetes endapan urin diteteskan pada objek glass dan ditutup dengan cover glass, setelah itu diamati dibawah mikroskop cahaya pada perbesaran $400 \mathrm{x}$.

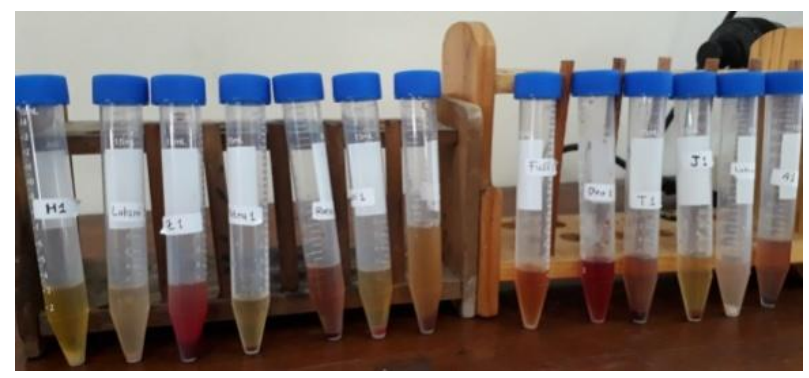

Gambar 1 Sampel urin kucing dengan gejala feline urologic symdrome (FUS) dari klinik hewan La Femur Surabaya.

\section{- HASIL DAN PEMBAHASAN}

Hasil pemeriksaan laboratorium dari 15 sampel urin sebanyak 8 ekor kucing positif ditemukan adanya albumin $(53,3 \%)$. Tes protein menggunakan kit dipstick jauh lebih sensitif untuk mendeteksi albumin dibandingkan untuk

Diterima: 11-07-2019 | Direvisi: 15-08-2019 | Disetujui: 20-08-2019 () 2019 CC-BY-SA. Ini adalah artikel Open Access yang didistribusikan berdasarkan ketentuan dari Creative Commons Attribution ShareAlike 4.0 International License (https://creativecommons.org/licenses/by-sa/4.0/). 
mendeteksi kadar globulin (Galgut 2013). Proteinuria adalah manifestasi pada penyakit ginjal dan indikator menurunnya fungsi ginjal. Protein dalam filtrat glomerolus akan diresorbsi oleh sel epitel tubulus proksimal, kemudian mengalami endositosis, selanjutnya mengalami degradasi oleh lisosom menjadi asam asam amino. Bila nefron mengalami kerusakan maka akan terjadi penurunan laju filtrasi glomeruli dimana ginjal mengalami gangguan dalam fungsi ekskresi dan non ekskresi sehingga dapat melanjut menjadi penyakit ginjal kronis (Yanuartono dkk. 2017). Albumin dalam urin mengindikasikan adanya gangguan pada membran glomerolus, sehingga dapat meloloskan molekul protein di dalam urin (Kusumawati \& Sardjana 2006). Selain dapat meloloskan protein, dalam urin juga ditemukan eritrosit (hematuria). Hematuria ditemukan pada penelitian ini sebanyak 12 ekor kucing (80\%). Penyebab hematuria antara lain trauma, peradangan, urolithiasis, neoplasia, koagulopati, dan penyakit infeksi saluran perkemihan (Galgut 2013). Menurut Tariq et al. (2014), penyebab infeksi bakteri pada FLUTD antara lain E. Coli, Enterococcus spp, Staphylococcus felis dan Corynebacterium urealyticum.

Gambar 2 menunjukkan hasil pemeriksaan mikroskopis pada urin kucing. Kristal kalsium oksalat ditemukan pada 6 ekor kucing (40\%), triple phosphat (struvit) dari 2 ekor kucing (13\%) dan 7 ekor tidak ditemukan kristal (47\%). Kristal kalsium oksalat dihydrat memiliki bentuk persegi dengan $\mathrm{X}$ di dalamnya dan tidak berwarna, sedangkan kalsium oksalat monohidrat mempunyai ciri antara lain berbentuk memanjang, tidak berwarna, memiliki 6 sisi datar, dan sejajar dengan ujung (Schendel 2012). Kristal kalsium oksalat terbentuk pada urin yang bersifat asam dan kadar kalsium yang tinggi dalam darah (Nash 2008). Kristal struvit terbentuk pada urin yang bersifat alkalis, berasal dari magnesium, ammonium dan phospat (Fossum 2002). Infeksi bakteri yang memproduksi urease dapat meningkatkan pembentukan kristal struvit dalam urin. Urease adalah enzim yang akan menghidrolisis urea dan menghasilkan ion amonia dan karbonat. Ion ammonium menyebabkan $\mathrm{pH}$ urin meningkat sehingga akan menurunkan solubilitas magnesium phospat dan meningkatkan pembentukkan struvit (Fossum, 2002).
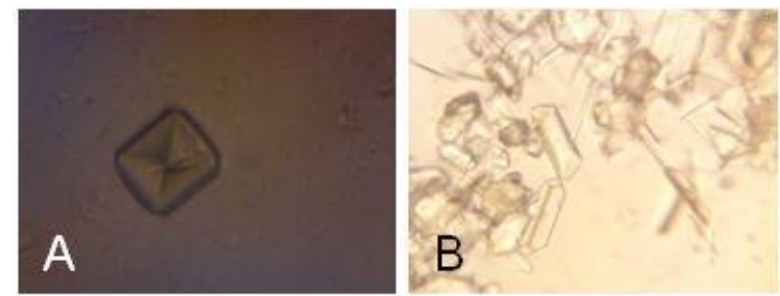

Gambar 2 Pemeriksaan mikroskopis pada urin kucing dengan gejala Feline Urologic Symdrome (FUS) dari klinik hewan La Femur Surabaya (Perbesaran 400x). (A) Kristal kalsium oksalat dihydrat. (B) Kristal struvit.

\section{- SIMPULAN}

Profil urin kucing dengan gejala feline urologic symdrome di Klinik Hewan La Femur Surabaya mengandung albumin dan ditemukan adanya eritrosit dengan jenis kristal kalsium oksalat dan struvit.

\section{- INFORMASI PENULIS}

Penulis untuk Korespondensi

*DA: desty.apritya@gmail.com

Laboratorium Bedah dan Radiologi, Fakultas Kedokteran Hewan, Universitas Wijaya Kusuma, Surabaya.

$\dagger$ SSK: sinawangsuryaningkartika@gmail.com

Klinik Hewan La Femur, Surabaya

\section{- PUSTAKA ACUAN}

Fauziah H. 2015. Gambaran cystitis melalui pemeriksaan klinis dan laboratoris (uji dipstik dan sedimentasi urin) pada kucing di Klinik Hewan Makasar. [Skripsi]. Fakultas Kedokteran, Universitas Hasanuddin Makassar.

Fossum TW. 2002. Small Animal Surgery. 2nd ed.Mosby ST, London. Galgut B. 2013. SA34-Urinalysis-A Review. The Dr. Jack Walther 85th Annual Western Veterinary Conference. Mandalay Bay Convention Center, Las Vegas, Nevada, February 17-21, 2013.

Hostutler RA, Chew DJ, Dibortola SP. 2005. Recent concepts in feline lower urinary tract disease. Veterinary Clinics: Small Animal Practice. 35(1): 147-170.

Kerr KR. 2013. Companion animal symposium: Dietary management of feline lower urinary tract symptoms. Journal of animal science, 91(6): 2965-2975.

Kusumawati D, Sadjana IKW. 2006. Perbandingan pemberian cat food dan pindang terhadap $\mathrm{pH}$ urin, albuminuria dan bilirubiunuria kucing. Media Kedokteran Hewan. 22(2): 131-135.

Little SE. 2012. The Cat: Clinical Medicine and Management. Elsevier. Canada.

Mihardi AP, Paramita IM, Pakpahan SN, Widodo S. 2018. KIVSA-4 Identifikasi klinis kristaluria pada kasus feline lower urinary track disease (FLUTD) di Klinik Hewan Maximus Pet Care. Proc. of 20th FAVA Conggress \& the 15th KIVNAS PDHI: 308-310.

Nash, H. 2008. Urine Crystals and Bladder Stones in Cats: Formation, Diet and other Treatment. http://www.peteducation.com/article.cfm?c=1+2243+2244\&aid=2660 (29 November 2017)

Schendel P. 2012. Are you Missing Out On A Golden Opportunity? Performing In- House Urinalysis - Sediment Evaluation. 2012 Speaker Notes - Indiana Veterinary Medical Association. https://invma.site-ym.com/page/298\#

Tariq A, Rafique R, Abbas SY, Khan MN, Huma I, Perveen S, Kamran M. 2014. Feline lower urinary tract disease (FLUTD) - an emerging problem of recent era. Journal of Veterinary Science \& Animal Husbandry. 1(5):503.

Yanuartono Y, Nururrozi A, Indarjulianto S. 2017. Penyakit ginjal kronis pada anjing dan kucing: manajemen terapi dan diet. Jurnal Sain Veteriner. 35(1): 16-34. 